\title{
Munda Tribe Perception Towards Livelihood Through Sustainable Development
}

\author{
Sposób na życie plemienia Munda \\ w kontekście wymagań zrównoważonego rozwoju
}

\author{
Laxmi Kumari*, Mojibur Rahman** \\ *Department of Humanities and Social Sciences, Indian Institute of Technology (ISM), \\ Dhanbad-826004, Jharkhand, India \\ E-mail (Corresponding Author): laxmi.2015dr0258@hss.iitism.ac.in \\ ORCID: 0000000252766070 \\ ${ }^{\star *}$ Department of Humanities and Social Sciences, Indian Institute of Technology \\ (ISM), Dhanbad-826004, Jharkhand, India \\ E-mail: mrahmanelt@iitism.ac.in
}

\begin{abstract}
The purpose of the present study is to portray the perception of tribal communities towards sustainable development. The motive of the study is to depict awareness which these tribal communities imbibe in themselves from primitive times. The idea to study Munda tribe of Jharkhand is because they are large in numbers, and will easily represent their outlook towards importance of preserving forest and livelihood development. The study focused on socio-capital and cultural understanding of the tribe in their livelihood. It emphasized on importance of women in the development of better livelihood. It showed how Non-Wood Forest Products (NWFP) are used in commercial and industrial form without affecting the natural resources, thus promotes sustainable development. The study also defined how through sustainable livelihood the tribe contributed in the revenue of the state government and also helped in generating income for the weaker section of the community.
\end{abstract}

Key words: sustainable development, Munda tribe, Non-Wood Forest Product (NWFP), livelihood

\section{Streszczenie}

Celem niniejszego opracowania jest omówienie postrzegania świata przez społeczności plemienne w kontekście zrównoważonego rozwoju. Motywem badania jest zobrazowanie świadomości, którą te społeczności plemienne przyswajają sobie od pokoleń. Za wyborem Munda z Jharkhand przemawiała jego duża liczebność. Dzięki niej możliwe będzie głębsze spojrzenie na ich wizję znaczenie ochrony lasów i zapewnienia źródeł utrzymania. Badanie koncentrowało się na społeczno-kapitałowym i kulturowym rozumieniu plemienia jako źródła utrzymania. Podkreślono znaczenie kobiet w rozwoju i drodze do lepszych warunków życia. Pokazano w jaki sposób niedrzewne produkty leśne (NWFP) są wykorzystywane w formie komercyjnej i przemysłowej, bez negatywnego wpływu na zasoby naturalne, promując zarazem w ten sposób zrównoważony rozwój. Badanie określiło również, w jaki sposób poprzez zrównoważone środki do życia plemię wnosiło wkład w dochody rządu stanowego, a także pomagało w generowaniu dochodów dla słabszej części społeczności.

Słowa kluczowe: rozwój zrównoważony, plemię Munda, NWFP, środki do życia 


\section{Sustainable development}

Sustainable development is development that meets the need of the present without compromising the ability of future generations to meet their own needs (Brundtland Commission Report 1987). Sustainable development is in the news everyday as the world copes with climate change, biodiversity loss, conflict and resource scarcity. Living within our environment limits is one of the central principles of sustainable development. But the focus of sustainable development is far broader than just the environment. It is also about ensuring a strong and healthy society. This means meeting the diverse needs of all people in existing and in future communities, promoting personal well-being, social cohesion and inclusion, and creating equal opportunity. Sustainable development is the process of organizing the environment in such a way that it exists longer in the future. The overall goal of Sustainable development is the longterm stability of the economy and environment; that is only achievable through the integration and acknowledgement of economic, environmental, and social concerns throughout the decision-making process.

The key principle of sustainable development underlying all others is the integration of environment, social, and economic concerns into aspects of decision making (Derwoach J.C., 2003; Stoddart, 2011). Sustainable development requires the integration of economic, environmental, and social objectives across sectors, territories, and generations. Therefore, sustainable development requires the elimination of fragmentation; that is, environmental, social and economic concerns must be integrated throughout decision-making processes in order to move towards development that is truly sustainable. Environmental stresses are linked with one another. Deforestation, by increasing run off, accelerates soil erosion and siltation of rivers and lakes. Air pollution and acidification play with part in killing forests and lakes. Thus, agricultural policies may lie at the root of land, water, and forest degradation. Energy policies are associated with the global greenhouse effect, with acidification, and with deforestation for fuelwood in many developing nations. These stresses threaten economic development. Thus, economics and ecology must be completely integrated in decision-making and lawmaking process not just to protect the environment, but also to protect and promote development. Economy is not just about the production of wealth, and ecology is not just about the protection of nature; they are both equally relevant for improving the humankind.

\section{Tribal's Association with Forest}

The loss of forest and other wild ground curbs the types of plants and creatures that radically decreases the hereditary assorted variety of the world's environments. This procedure ransacks present and people in the future of hereditary material with which to improve crop assortments, to make them less powerless against climate stress, bother assaults, and illness. The loss of species and subspecies, up till now is unstudied by science, denies us of significant potential wellsprings of drugs and mechanical synthetic concoctions. It expels always animals of excellence and parts of our social legacy; it lessens the biosphere.

Human resource development is a critical necessity not exclusively to develop specialized information and abilities, but in addition to make new qualities to support people and countries, to adapt quickly natural, and real factors.

Ancestral and indigenous people community will require special consideration as the powers of monetary advancement upset their conventional ways of life - ways of life that can offer present day social orders numerous exercises in the administration of assets in complex woods, mountain, and dryland environments. Some are undermined with virtual eradication by coldhearted improvement over which they have no control. Their conventional rights ought to be perceived and they ought to be given an unequivocal voice in figuring arrangements about asset improvement in their territories.

Development in world grain production has consistently surpassed total populace development. However, every year there are more individuals on the planet who don't get enough food. Worldwide farming can possibly develop enough nourishment for all; however, food is frequently not accessible where it is required. Creation in industrialized and allied nations has been exceptionally sponsored and shielded from worldwide rivalry. These sponsorships have energized the abuse of soil and synthetic substances, the contamination of both water assets and nourishments with these synthetic compounds, and the corruption of the open country. Quite a bit of this exertion has delivered surpluses and their related budgetary weights. Furthermore, a portion of this excess has been sent at concessional rates to the creating scene, where it has sabotaged the cultivating arrangements of beneficiary countries. There is, in any case, developing mind in certain nation of the ecological and monetary outcomes, and the accentuation of rural arrangements is to empower protection.

The tribal communities of India are like in a developing stage. It is witnessing different stages of deformation. The tribes differ from one another in their traditions, customs and atypical way of living. These communities are scattered in different geographical space of the country. Many of these communities still survive in rural areas and they survive on forest resources. There are number of welfare programs instigated by the Government for the betterment of the communities but they are not executed the way it 
should have been. The programs have not been effective for the lack of combination with their way of life.

Formerly, the tribal living was self-sufficient dependent upon subsistence economy. These tribal communities sustained their life with restricted requirement like hunting, wood cutting, food gathering and with some minimal forest products. Forest was their source of income and their livelihood, it helped them to develop socially and economically. However, the indigenous experience, abilities and conventional acts of the tribal have not increased a lot of interest about them. The tribes differ from one another in their traditions, customs and atypical way of living. These communities are scattered in different geographical space of the country. Many of these communities still survive in rural areas and they survive on forest resources. They still work hard for two times meal a day. From the ancient times, the tribal way of living was simple and self-sufficient based on the minimum necessity to support life. The clans met their livelihood with restricted means like hunting, food gathering and minor forest products. Forest has always helped the tribe in their socio-economic development. The indigenous knowledge and their traditional practices of tribal have not achieved much acceptance. In fact, they have always been controlled and their resources have been exploited, in result their subsistence economy was affected. Due to this exploitation, the tribal had to leave their forest and seek jobs as laborer's and daily wagers. They were dependent on season and availability of work, thus this change of living from tradition to new way living resulted in their loss of culture and identity. Their existence was questioned and their way of living lost its essence.

\section{Tribes in India}

A Tribe is, in an ideal state, a self-contained unit. It constitutes a society in itself. The anthropologist, Nadel, defines a society in this way, societies are made of people; societies have boundaries, people either belong to them or not; and people belong to a society in virtue of rules under which they stand, and which impose on them regularly determinate ways of acting towards and in regard to one another. Tribe is considered as collection of individuals sharing a common culture. Tribe is a society having a clear linguistic boundary and generally a well-defined political boundary. It is within the latter that regular determinate ways of acting are imposed on its members. The tribe also has a cultural boundary, much less well-defined, and this is the general frame for the formal and informal interactions of these members. The tribes or tribal communities in India are defined by the Constitution of India as Scheduled Tribes deemed under Article 342. The tribal habitation in India is segregated in three tribal zones: North-eastern, Central and Southern. The tribes sometimes called aboriginals because of their being the earliest inhabitants of this country, not only belong to different stages of culture, but they vary from area to area in regard to size of the population language, racial types, socio-economic organization, etc... The largest concentration of tribal people anywhere in the world except Africa, is in India and it is interesting to note that there are six hundred and thirty tribes inhabited all over India. There are as many as thirty-two tribes only in Jharkhand, but among them four tribes can be treated to be significant; Munda, Oraon, Santhal and Ho.

\section{Primitive Tribes of Jharkhand}

The history of habitation of tribes in Jharkhand has been long since primitive days as it is evident from the history but there is no other document or any other source of information to be relied upon. Prehistorically, the state of Jharkhand, formerly known as Chotanagpur, was a land of forest. It was rich in minerals. But it was not suitable for incoming migrants to settle and make use of the minerals. Such incoming migrants inhabited in the river plains and restricted their development in economic and cultural activities only. Thus, Jharkhand remained occupied by the Adivasi for long in which Kharia, Virhore and Asur are the main primitive tribal of Chotanagpur, Munda, Oraon and Ho came later on. During the ancient period migrants from Central India and Uttar Pradesh who entered into Jharkhand were Mundas, Kharia and Virhore, through the way of mountain range of Kaimur.

The Mundas are the dominant and the indigenous tribe of Jharkhand, found mostly in Chotanagpur plateau eastern region. The Mundas belong to the Austro-Asiatic language family and some of the related tribes are Munda, Santhal and Ho. They share same cultural and traditional values and customs. The tribes often live on fishing, hunting or gathering food, they were highly dependent on forest. Their life revolves around forest and its products. They were mostly Hunter-gatherer type, based on shifting agriculture, they were simple artisans and few were settled agriculturists.

\section{Situation of Munda Tribe in Jharkhand}

Most primitive tribes who spoke the Austro-Asiatic language (like the Santhal, Munda, Ho, Bhumji, Kharia, Kharwar, Korwa, and the Oraon tribes) were labeled as the Kol. There languages were placed in sae family of languages, better known as the Mundari or the Austro-Asiatic language group. Incidentally, this distinctive family of languages bears many resemblances to the one spoken by the aborigines of Australia. During the colonial British period the name Kol acquired a negative connotation. It became a synonym for savage, lowly, militant and aggression and for those performing menial jobs. 
Munda is a typical representation of the great $\mathrm{Kol}$ race. Mundas are the tribal communities from the south East Asia. They are dark brown almost black in colour, short in height but sturdy in their limbs, with irregular features, scanty beards, thick lips, broad nose, a low facial angle, with a head long than that of the average Dravidian's.

According to 2001 census report this tribe is concentrated basically in Ranchi, Pashchimi Singhbhum, Palamu, Purbi Singhbhum and Gumla districts respectively. Santhal, Munda and Ho share, to some extent, a symbolic system that values the forest, represented in the village by the sacred grove. Berger \& Heidemann (2013) Despite the fact that tribal are not Hindu, they pursuit only nature. Modern technology and industrialization have knocked the tribal area in Jharkhand but both couldn't change the tribal values. Tribal always believes in egalitarian society, so there is no space for classicism in tribal society of Jharkhand. Tribal made farms and are still engaged in farming. They believe that hill, river and forest are lifelines of tribal society in Jharkhand. They can do anything to save them. In present India, Munda tribe has been affected by non-tribal interference and reservation of forest. Many other tribal groups are facing problem of displacement due to urbanizations, and industrializations. When a group of tribe goes to urban area or city, they lose their tribalism. It is a bitter truth that tribal area is full of natural resources because of which they face commercial exploitation by both the corporate world and Naxals.

\section{Socio-Capital and Cultural Development among Munda Tribe}

The socio-capital is to deal with social relations and informal interaction between the individuals. Sociocapital elucidates practically a circumstance where individuals share same feeling of character, have parallel qualities, trust one another and correspondingly get things done for one another. The idea of the socio-capital development relies upon different elements of the communications in which it is created, for example, the nature of the interior outside connections, correspondence, trust and the mutual qualities and standards. social capital alludes to the connections among individuals and not simply individuals themselves. Socio-capital is an imperceptible type of capital as it expands upon inconspicuous social structures and connections that structure the establishment of systems. Tribal women hold a significant position in the tribal community. Their livelihood is connected with the division of work between the people in the network. Each society has its sociocultural characteristics that are procured from what female and male of the general public are required to do in their life. Gender roles alludes to the practices, mentalities, qualities and convictions that a specific culture thinks about standardizing for one's natural gender. Gender roles jobs are examples in a given society that play out the gender division of work for example which exercises; assignments and obligations performed by male and female. The tribal women are often seen in the field in cutting and harvesting crops. It is an apparent conduct standard related especially with males or females, in a given social gathering or framework. Female are generally, by division of work, answerable for asset assembly and the board. Water, Fire wood assortment are the acknowledged obligations of female. The sort of exercises individuals from family units are associated with add to their family unit government assistance and dynamic capacities. In the past the Gender roles execution of people add to one another in method of division of work by sharing their works in the family and network, in light of their physical nature. The term gender equality has given the females equivalent right to practice in the general public. Women's cooperation in the development program can enable them to empower in the equivalent right with males.

\section{Non-Wood Forest Product (NWFP) and Sustain- able Livelihood for Munda Tribe}

Non-wood Forest Product means by product of forest. It is defined as goods and services used for commercial and industrial purposes without use of direct forest product like timber, rather it uses biomass or materials derived from forest ecosystem. The Munda tribe are forest dwellers and these tribe know the importance of forest and their valuable contribution towards sustainable development of the society and country. They know the roles of forest and the direct forest products like the raw materials, such as trees and woods, so they are always against the industrialization process which harms the forest land. They always want to preserve their forest, but forest is also their source of income. They are highly sensitive towards these forest lands. The Munda Tribal community has gained its sustainable livelihood from these forest in the form of some small-scale business. The tendu leaves is used in commercial purpose for making local bidis, and at present it gives lot of revenue to the state government. Its fruit is also eaten and sold commercially. Its bark is burnt by the tribal and are used to cure small-pox. The leaves are also used in transportation, it is used in packaging. Eating plates are also made with the tendu leaves. It is a very important source of income for this tribe as this tribe is densely populated in the Chotanagpur plateau of Jharkhand.

Another way of their sustainable livelihood is tribal herbal treatment. Tribal have customarily relied upon their customary techniques for recuperating/treatment for minor everyday afflictions and the significant ones as well. There is a requirement for developing another methodology of consolidating the indigenous inborn medication with other clinical systems. A deliberate exertion should be made to report this customary ancestral information on thera- 
peutic/home grown plants, normalizing it and remembering it as a free arrangement of medication. The neighborhood tribal particularly the customary healers can be prepared and be depended with the obligation of treating the people on compensation, etc. Animal husbandry, poultry and fishing are also their source of income. These works are also done on small scale and its mostly done from their home.

\section{Needs and Significance of the Study}

The significance of the study is to direct visibility on the tribal community of Jharkhand, India and their contribution towards sustainable development of the society. The tribal community is extracting their livelihood from the forest product and is also significantly helping in the development of the community. It has reflected on the socio-capital resources of the tribe and the importance of women in the development of the well-being of the tribe. It has also suggested strategies like medical treatment with the help of herbal plants to promote sustainable livelihood for Munda tribe.

\section{Conclusion}

The study emphasized on Socio-capital and cultural understanding of men and women in their livelihood development. It focused on the use of Non-Wood Forest Product (NWFP) in order to promote sustainable development. The study took into consideration mainly Munda tribe because of their dense population in the Chotanagpur plateau of Jharkhand. It wanted to portray the attitude of Munda tribe towards sustainable development. It wanted to make visible that the Munda tribe, being the primitive tribe, is very well aware by the importance of preserving forest. Their perception towards sustainable development is appreciable, as they are not that literate and versed like the other communities. The study also reflected how through their livelihood the state is getting revenue and are also helping in generating income for their survival.

\section{References}

1. BRODHAG C., TALIERE S., 2006, Sustainable development strategies: Tools for policy coherence, in: Natural Resources Forum, p. 136-145.

2. DERNBACH J. C., 1998, Sustainable development as a framework for national governance, Case Western Reserve Law Review, p. 1-103.

3. EMAS R. 2015, The Concept of Sustainable Development: Definition and Defining Principles, Brieffor GSDR 2015, Florida International University, p. 13.

4. KERKETTA J. K., 2016, Studies on Productivity, Silviculture and Socio-economics of 'Diospyros melanoxylon' Roxb. in Jharkhand, Ph.D. Thesis, Chapter 1: Introduction, p. 1-5.

5. MINZ D., HANSDA D. M., 2010, Encyclopaedia of Scheduled Tribes in Jharkhand, Gyan Publishing House.

6. Planning Commission Government of India, 2013, Twelfth Five Year Plan vol. 3, The Sage Team: Rudra Narayan, Archita Mandal, Rajib Chatterjee and Dally Varghese, p. 1-273.

7. ROY S. C., 2010, The Mundas and their country. Ranchi: Crown Publications.

8. SABAR B., NAYANTARA S.N., LALITH A., 2016, Tendu Leaves Collection in India Livelihood, Rights and Challenges for Alternative to Tobacco-Evidences from Five Indian States, in: Journal of Governance \& Public Policy, 6(1), p. 106-126.

9. SCOONES I., 1998, Sustainable Rural Livelihoods: A Framework for Analysis, IDS Working Paper 72, Brighton: IDS.

10. SUJEESH M. K., 2014, Role of gender and social capital in sustainable livelihood promotion of Kadar tribe in Kerala.

11. THAKUR D. T. D., 2009, Tribal Life and Forests vol 1 , Deep and Deep Publications.

12. The Official Definition of Sustainable Development, https://youmatter.world/en/definition/definitionssustainable-development-sustainability/, $(1.05 .2020)$

13. UNITED NATIONS, 1987, Report of the World Commission on Environment and Development: Our common future, Oxford University Press, New York.

14. VIDYARTHI L. P., RAI B. K., 1977, The tribal culture of India, Concept Publishing Company. 
